\title{
MIR191 wt Allele
}

National Cancer Institute

\section{Source}

National Cancer Institute. MIR191 wt Allele. NCI Thesaurus. Code C105989.

Human MIR191 wild-type allele is located in the vicinity of 3p21.31 and is 92 bases in

length. This allele, which encodes MIR191 pre-miRNA, may play a role in the regulation of transcription. 